\title{
三嗪衍生物苂光探针对 $\mathrm{Zr}^{4+}, \mathrm{Fe}^{3+}$ 和丙酮的识别
}

\author{
马学林 $a, b$ 韩利民 $*, a$ 张骁勇 $*, b$ 张玉恒 ${ }^{b}$ 王 丽 $b$ \\ 杨 坤 $b$ 冀 婕 ${ }^{b}$ \\ $\left({ }^{a}\right.$ 内蒙古工业大学化工学院 呼和浩特 010051) \\ ( $b$ 包头师范学院化学学院 内蒙古包头 014030)
}

\begin{abstract}
摘要 一锅法合成了 2,2',2"-(1,3,5-三嗪-2,4,6-三亚胺基)三苯甲酸苂光响应化学传感器( $\mathbf{L}, \mathbf{H}_{3}$ TATIB), 系统地研究了化 合物 $\mathbf{L}$ 对过渡金属离子的识别性能. 实验结果显示, 在 $N, N$ 二甲基甲酰胺(DMF)水溶液中实现了对 $\mathrm{Fe}^{3+}$ 和 $\mathrm{Zr}^{4+}$ 的识别; 化合物 $\mathbf{L}$ 在有机溶剂识别中能够有效地识别丙酮. 化合物 $\mathbf{L}$ 对 $\mathrm{Zr}^{4+}$ 和 $\mathrm{Fe}^{3+}$ 的检测限分别为 $3.60 \times 10^{-6}$ 和 $1.33 \times 10^{-6}$ $\mathrm{mol} / \mathrm{L}$. 实验初步探究了化合物 $\mathbf{L}$ 作为荧光探针对人体尿液和水样中 $\mathrm{Fe}^{3+}$ 离子的识别.

关键词 苂光传感器; $\mathrm{Zr}^{4+}$ 离子; $\mathrm{Fe}^{3+}$ 离子; 丙酮; 1,3,5-三嗪衍生物
\end{abstract}

\section{Triazine Derivative for Fluorescence Sensing of $\mathrm{Zr}^{4+}, \mathrm{Fe}^{3+}$ lons and Acetone}

\author{
Ma, Xuelin ${ }^{a, b}$ Han, Limin*a $\quad$ Zhang, Xiaoyong*, ${ }^{*}$ Zhang, Yuheng ${ }^{b}$ \\ Wang, $\mathrm{Li}^{b} \quad$ Yang, $\mathrm{Kun}^{b} \quad \mathrm{Ji}, \mathrm{Jie}^{b}$ \\ ( ${ }^{a}$ Chemical Engineering College, Inner Mongolia University of Technology, Hohhot 010051) \\ ( ${ }^{b}$ Department of Chemistry, Baotou Teachers' College, Baotou, Inner Mongolia 014030)
}

\begin{abstract}
Triazine-2,4,6-triimino)tribenzoic acid (L, H3 TATIB) fluorescence response chemosensor has been synthesized by one pot reaction and its fluorescent behaviors to transition metal ions were systematically investigated. The experimental results show that the recognition of $\mathrm{Zr}^{4+}$ and $\mathrm{Fe}^{3+}$ is realized in $N, N$-dimethylformamide (DMF) aqueous solution; The compound $\mathbf{L}$ can effectively detect acetone in organic solvent. The detection limits of $\mathrm{Zr}^{4+}$ and $\mathrm{Fe}^{3+}$ are $3.60 \times 10^{-6}$ and $1.33 \times 10^{-6} \mathrm{~mol} / \mathrm{L}$, respectively. It was preliminarily explored that compound $\mathbf{L}$ was used as a fluorescent probe to identify $\mathrm{Fe}^{3+}$ ion in human urine and water samples.

Keywords fluorescent sensor; $\mathrm{Zr}^{4+}$ ion; $\mathrm{Fe}^{3+}$ ion; acetone; 1,3,5-triazine derivatives
\end{abstract}

\section{Introduction}

The sensing and detection of hazardous substances plays an important role in life and environmental sciences. The past decade has witnessed a fast growth for detection of $\mathrm{Fe}^{3+}$ ion because massive utilization of $\mathrm{Fe}^{3+}$ ion causes environmental pollution and health problems. ${ }^{[1 \sim 7]}$ It is well known that the $\mathrm{Fe}^{3+}$ ion plays an important role in biological metabolism and are recognized as an industrial pollutant. However, these widely used instrumental analytical techniques have some limitations, including expensive equipment, complication in sample preparation and well-trained person. To defeat this problem, the large number of well-designed sensors based on this $\mathrm{Fe}^{3+}$ ion have been developed by fluorescent ${ }^{[8 \sim 18]}$ and colorimetric $^{[19]}$ sensing methods, of which sensitive and selective detections of $\mathrm{Fe}^{3+}$ ion by fluorescent methods are most competitive and have attracted great attention in recent years. Although metal-organic frameworks (MOFs) as fluorescent probe have been widely investigated for their potential application in the sensitive and selective detection of $\mathrm{Fe}^{3+}$ ion, many MOFs are limited in wide application

\footnotetext{
* Corresponding authors. E-mail: 66123@bttc.edu.cn; hanlimin@imut.edu.cn

Received December 6, 2019; revised February 27, 2020; published online March 31, 2020.

Project supported by the Natural Science Foundation of Inner Mongolia (Nos. 2018BS02009, 2019MS02031), the Young Innovative Talents in Baotou City (No. 30324001), the National Natural Science Foundation of China (Nos. 21767021, 51563019) and the Education Department Project of Inner Mongolia (No. NJZY19187).

内蒙古自然科学基金(Nos. 2018BS02009, 2019MS02031)、包头市青年创新人才(No. 30324001)、国家自然科学基金(Nos. 21767021, 51563019)和内蒙 古教育厅(No. NJZY19187)资助项目.
} 
due to complicate operations, slow signal response, poor stability, ${ }^{[20]}$ expensive raw materials, ${ }^{[21 \sim 24]}$ toxic (including heavy metal $)^{[25,26]}$ and not suitable for aqueous and biological environment. In addition, though $\mathrm{Zr}^{4+}$ is not classified as one of the essential elements for human and cannot also produce toxic effects for environment, it is a rare metal and very important atomic energy elements which is widely used in military industry, smelting, atomic energy industry and battery. ${ }^{[27,28]}$ However, up to now, there is only a small amount of detection of $\mathrm{Zr}^{4+}$ ion, ${ }^{[29]}$ mostly the recognition of $\mathrm{Fe}^{3+}$ ion by $\mathrm{Zr}(\mathrm{IV})-\mathrm{MOFs} .{ }^{[30,31]}$ Besides, MOFs are also used as fluorescent probes to detect small molecular compounds, such as $\mathrm{H}_{2} \mathrm{~S},{ }^{[32]}$ biomolecules, ${ }^{[33]}$ acetone ${ }^{[34,35]}$ and nitroaromatic compounds. ${ }^{[36 \sim 38]}$ Therefore, there is an urgent need to develop a new chemosensor for the rapid selective and sensitive detection of $\mathrm{Zr}^{4+}, \mathrm{Fe}^{3+}$ ion and acetone as the replacement.

In this work, it reports an organic fluorescent probe $\mathbf{L}$ (no heavy metal ions and low toxicity) which is rationally designed on the basis of 2,4,6-trichloro-1,3,5-triazine and contains nine coordination centers (Figure 1). It exhibits strong fluorescence and highly sensitive and selective toward $\mathrm{Zr}^{4+}, \mathrm{Fe}^{3+}$ ions and acetone in room temperature. With the addition of $\mathrm{Fe}^{3+}$ ion, compound $\mathbf{L}$ could give rise to a visible colorless-to-yellow change and clear fluorescence quenching. In contrast to this, with the addition of $\mathrm{Zr}^{4+}$ ion, the compound shows fluorescence enhancement. This is the first example of fluorescent organic compound chemosensor for the highly selective detection of $\mathrm{Zr}^{4+}, \mathrm{Fe}^{3}$ + ions and acetone simultaneously based on 1,3,5-triazine derivatives with the highest density of uncoordinated $\mathrm{N}$ and carboxylate $\mathrm{O}$ atoms. This study might provide a new method for the rapid detection of $\mathrm{Zr}^{4+}, \mathrm{Fe}^{3+}$ ions and acetone with the advantages of simple sample pretreatment processes, highly sensitive and selective sensing.

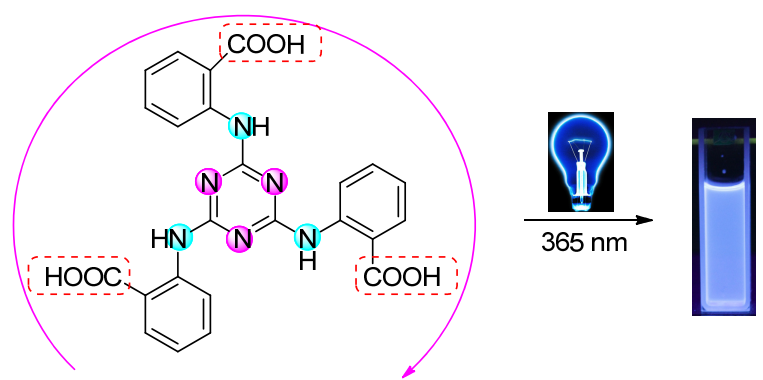

Figure 1 Structure and fluorescent of $\mathbf{L}$

\section{Results and discussion}

\subsection{Metal ions detection}

The fluorescent properties of the sensor $\mathbf{L}$ in $N, N$-dimethylformamide (DMF) are measured at room temperature. L exhibits strong fluorescent emission at $415 \mathrm{~nm}$. Furthermore, $\mathbf{L}$ is explored for the application in the detection of metal ions in DMF and water system based on fluorescent sensing. In the measurement, $1.2161 \mathrm{mg}$ of freshly prepared samples of $\mathbf{L}$ are dissolved in $250 \mathrm{~mL}$ DMF solution $\left(1 \times 10^{-5} \mathrm{~mol} \cdot \mathrm{L}^{-1}\right)$, to which is dropwise added different metal ions of aqueous solution. In this regard, the responses of the fluorescence of $\mathbf{L} / \mathrm{DMF}$ solution toward 15 different metal cations $\left(\mathrm{Zr}^{4+}, \mathrm{Fe}^{3+}, \mathrm{Co}^{2+}, \mathrm{Cr}^{3+}, \mathrm{Ni}^{2+}\right.$, $\mathrm{Cu}^{2+}, \mathrm{Cd}^{2+}, \mathrm{Pb}^{2+}, \mathrm{Ag}^{+}, \mathrm{Sr}^{2+}, \mathrm{Ba}^{2+}, \mathrm{Ca}^{2+}, \mathrm{Mg}^{2+}, \mathrm{Na}^{+}, \mathrm{K}^{+}$) in aqueous solution were studied and obtained experimental data finally (Figure 2). Obviously, most cations display a negligible influence on fluorescence intensity of L. Specifically, the fluorescence intensity of $\mathbf{L}$ at $415 \mathrm{~nm}$ changes slightly while $\mathrm{Co}^{2+}, \mathrm{Cr}^{3+}, \mathrm{Ni}^{2+}, \mathrm{Cu}^{2+}, \mathrm{Pb}^{2+}, \mathrm{Ag}^{+}$, $\mathrm{Sr}^{2+}, \mathrm{Ba}^{2+}, \mathrm{Ca}^{2+}, \mathrm{Na}^{+}$and $\mathrm{K}^{+}$ions were added respectively. It can see clearly that is that the fluorescence intensity of $\mathbf{L}$ decreases significantly, to which is added $\mathrm{Fe}^{3+}$ ion. Conversely, the fluorescence intensity of $\mathbf{L}$ increases significantly while $\mathrm{Zr}^{4+}$ ion is added. In addition, the compound $\mathbf{L}$ could rapidly give rise to a visible colorless-to-yellow change after adding $\mathrm{Fe}^{3+}$ ion and the experiments show that yellow is not caused by the color of $\mathrm{Fe}^{3+}$ ion itself.

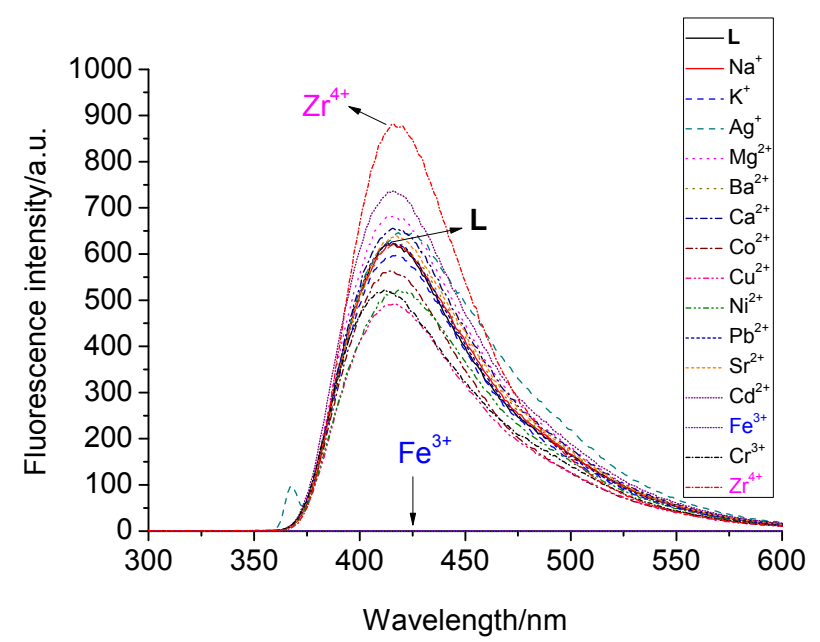

Figure 2 Fluorescence spectra of $\mathbf{L}\left(2.9 \mathrm{~mL}, 1 \times 10^{-5} \mathrm{~mol} \cdot \mathrm{L}^{-1}\right)$ with different metal cations $\left(0.1 \mathrm{~mL}, 10^{-1} \mathrm{~mol} \cdot \mathrm{L}^{-1}\right)\left(\lambda_{\mathrm{ex}}=365\right.$ $\mathrm{nm})$

\subsection{1 $\mathrm{Fe}^{3+}$ ion detection}

To explore the complexation ratio of $\mathbf{L}(2.9 \mathrm{~mL}, 1 \times$ $10^{-5} \mathrm{~mol} \cdot \mathrm{L}^{-1}$ ) with $\mathrm{Fe}^{3+}$ ion in DMF solution, concentration-dependent experiments were further taken by UV method (Figure 3a). The absorption intensity of $\mathbf{L}$ gradually decreased with the increasing concentration of $\mathrm{Fe}^{3+}$ ion. The Job's curve was given according to the UV concentration curve of $\mathbf{L}$ and $\mathrm{Fe}^{3+}$ ions (Figure $3 \mathrm{~b}$ ). The results showed that the molar fraction of $\left[\mathrm{Fe}^{3+}\right] /\left[\mathbf{L}+\mathrm{Fe}^{3+}\right]$ was 0.4 when the curve had inflection point, demonstrating $2: 1$ binding stoichiometry ration for $\mathbf{L}+\mathrm{Fe}^{3+}$. Moreover, to evaluate the detection effects of $\mathbf{L}$ to $\mathrm{Fe}^{3+}$ ion, the fluorescence spectra of $\mathbf{L}$ in $\operatorname{DMF}\left(2.9 \mathrm{~mL}, 1 \times 10^{-5} \mathrm{~mol} \cdot \mathrm{L}^{-1}\right)$ with different concentrations of $\mathrm{Fe}^{3+}$ ion were carried out (Figure $4 \mathrm{a}$ ). The experimental result showed that with the addition of different concentrations $\mathrm{Fe}^{3+}$ ion, the fluorescence intensity of $\mathbf{L}$ gradually decreases and shows a highly broad linear relationship with the concentration of $\mathrm{Fe}^{3+}$ ion from $1 \times 10^{-6}$ to $1 \times 10^{-5} \mathrm{~mol} \cdot \mathrm{L}^{-1}$ expressed as an equation of $y=41790.2576 x+0.0406$ and $R^{2}=0.99905$, 
where $y$ is the ratio of $\left(F_{0}-F\right) / F_{0}$ and $x$ is the concentration of $\mathrm{Fe}^{3+}$ ion. The other reported sensors for $\mathrm{Fe}^{3+}$ ion detection are generally within $1.25 \times 10^{-3} \mathrm{~mol} \cdot \mathrm{L}^{-1}$ of $\mathrm{Fe}^{3+} \cdot{ }^{339,40]}$ According to the fluorescence intensity of $\mathbf{L}$, different concentration of $\mathrm{Fe}^{3+}$ and Benesi-Hildebrand equation, the detection limit of $\mathrm{Fe}^{3+}$ in $\mathbf{L}$ solution is calculated to be $1.33 \times 10^{-6} \mathrm{~mol} / \mathrm{L}$ (Figure $4 \mathrm{~b}$ ).
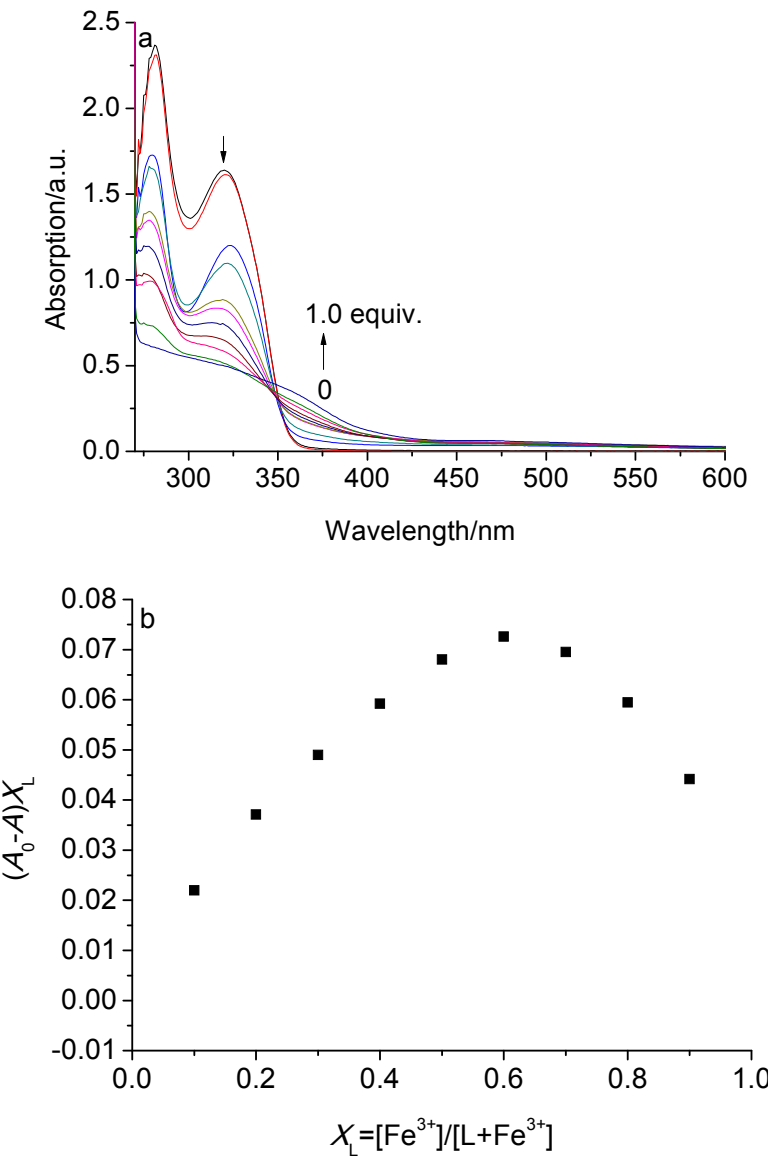

Figure 3 (a) UV-vis spectra of $\mathbf{L}$ with different concentration $\mathrm{Fe}^{3+}$ and (b) Job's plot of $\mathbf{L}$ with $\mathrm{Fe}^{3+}$

(a) $[\mathbf{L}]=2.9 \mathrm{~mL}, 1 \times 10^{-5} \mathrm{~mol} \cdot \mathrm{L}^{-1} ;\left[\mathrm{Fe}^{3+}\right]=0.1 \mathrm{~mL}, 1 \times 10^{-6} \sim 10 \times 10^{-5}$ mol $\cdot \mathrm{L}^{-1}$. (b) complexation ratio of $\mathbf{L}$ and $\mathrm{Fe}^{3+},\left[\mathrm{Fe}^{3+}\right]=0.1 \mathrm{~mL}, 1 \times$ $10^{-6} \sim 10 \times 10^{-5} \mathrm{~mol} \cdot \mathrm{L}^{-1}$

Obviously, the addition of different concentration $\mathrm{Fe}^{3+}$ ion to the DMF solution of $\mathbf{L}$ could give rise to a visible colorless-to-yellow change, and clear fluorescence quenching while the concentration of $\mathrm{Fe}^{3+}$ is up to $10 \times 10^{-3}$ $\mathrm{mol} \cdot \mathrm{L}^{-1}$ (Figure 5 ). The initial fluorescence intensity of $\mathbf{L}$ $\left(1 \times 10^{-5} \mathrm{~mol} \cdot \mathrm{L}^{-1}\right)$ was decreased by $99.9 \%$ when only 0.1 $\mathrm{mL}\left(1 \times 10^{-1} \mathrm{~mol} \cdot \mathrm{L}^{-1}\right) \mathrm{Fe}^{3+}$ was added. Further, the quenching efficiency can be rationalized by the SternVolmer (SV) equation, $F_{0} / F=1+K_{\mathrm{SV}}[\mathrm{M}]$, where $F_{0}$ and $F$ are the relative fluorescence intensity before and after adding $\mathrm{Fe}^{3+},[\mathrm{M}]$ is the molar concentration of the $\mathrm{Fe}^{3+}$ ion, and $K_{\mathrm{SV}}\left(\mathrm{L} \cdot \mathrm{mol}^{-1}\right)$ is the Stern-Volmer quenching constant. The $K_{\mathrm{SV}}\left(\mathrm{Fe}^{3+}\right)$ value is calculated as $7.111 \times 10^{4}$ $\mathrm{L} \cdot \mathrm{mol}^{-1}$, suggesting a strong quenching effect on fluorescence. Under the same conditions, the quenching constants of other metals are shown in Table 1. The reason of fluo-
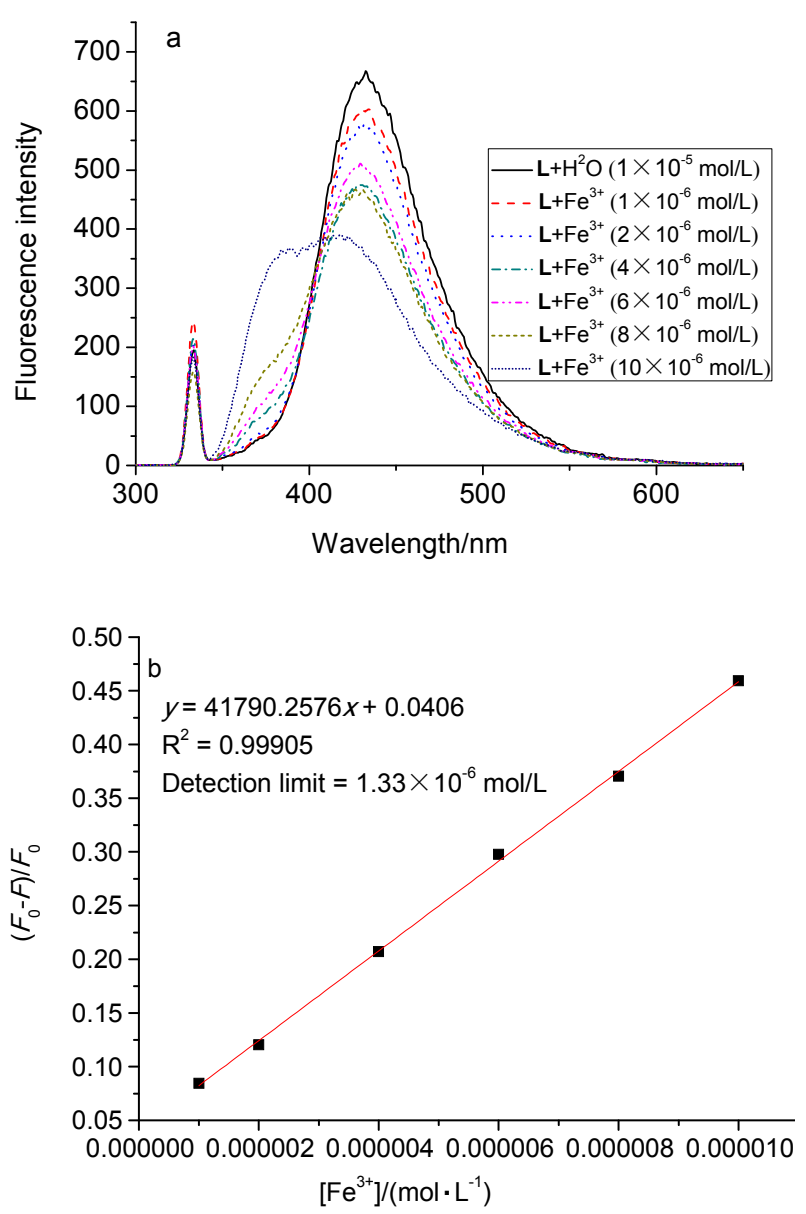

Figure 4 Fluorescence spectra (a) of $\mathbf{L}$ with different concentration $\mathrm{Fe}^{3+}$ and detection limit (b) of $\mathbf{L}$ with $\mathrm{Fe}^{3+}\left(\lambda_{\mathrm{ex}}=324 \mathrm{~nm}\right)$ (a) $[\mathbf{L}]=2.9 \mathrm{~mL}, 1 \times 10^{-5} \mathrm{~mol} \cdot \mathrm{L}^{-1} ;\left[\mathrm{Fe}^{3+}\right]=0.1 \mathrm{~mL}, 1 \times 10^{-6} \sim 10 \times 10^{-6}$ mol $\mathrm{L}^{-1}$; (b) Detection limit of $\mathrm{Fe}^{3+},\left[\mathrm{Fe}^{3+}\right]=0.1 \mathrm{~mL}, 1 \times 10^{-6} \sim 10 \times$ $10^{-6} \mathrm{~mol} \cdot \mathrm{L}^{-1}$

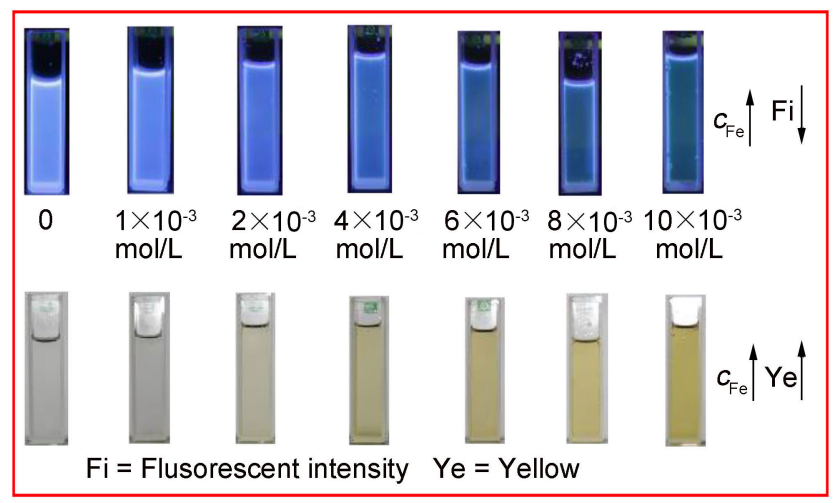

Figure 5 Photograph of $\mathbf{L}$ containing different concentrations of $\mathrm{Fe}^{3+}$ ion

rescence quenching may be that when $\mathrm{Fe}^{3+}$ and $\mathbf{L}$ form $2: 1$ complex, the structure is isomerized, the imine $(\mathrm{NH})$ bond is broken, and the bond length is shortened, which makes ligand $\mathbf{L}$ show color change when encountering $\mathrm{Fe}^{3+}$ ions. And there may be electron and energy transfer between the paramagnetism of $\mathrm{Fe}^{3+}$ and the unfilled $\mathrm{d}$ orbital in $\mathbf{L}$, which makes the fluorescence quenching. 
Meanwhile, the antijamming experiments of $\mathrm{Fe}^{3+}$ ion specifically demonstrate that $\mathbf{L}$ can detect $\mathrm{Fe}^{3+}$ ion in the presence of other metal ions $\left(\mathrm{Co}^{2+}, \mathrm{Ni}^{2+}, \mathrm{Cu}^{2+}, \mathrm{Pb}^{2+}, \mathrm{Ag}^{+}\right.$, $\mathrm{Sr}^{2+}, \mathrm{Ba}^{2+}, \mathrm{Ca}^{2+}, \mathrm{Na}^{+}, \mathrm{K}^{+}, \mathrm{Cd}^{2+}, \mathrm{Mg}^{2+}, \mathrm{Cr}^{2+}$ ) (Figure 6).

Table 1 Quenching constants of different metals in DMF solution of $\mathbf{L}^{a}$

\begin{tabular}{cc||cc}
\hline Cation & $\begin{array}{c}\text { Quenching constant/ } \\
\left(\mathrm{L} \cdot \mathrm{mol}^{-1}\right)\end{array}$ & Cation & $\begin{array}{c}\text { Quenching constant/ } \\
\left(\mathrm{L} \cdot \mathrm{mol}^{-1}\right)\end{array}$ \\
\hline $\mathrm{K}^{+}$ & 0.424 & $\mathrm{Na}^{+}$ & 0.071 \\
$\mathrm{Ag}^{+}$ & -0.323 & $\mathrm{Ca}^{2+}$ & -0.471 \\
$\mathrm{Ba}^{2+}$ & 0.071 & $\mathrm{Sr}^{2+}$ & -0.212 \\
$\mathrm{Co}^{2+}$ & 1.099 & $\mathrm{Cr}^{2+}$ & 2.000 \\
$\mathrm{Cu}^{2+}$ & 2.779 & $\mathrm{Ni}^{2+}$ & 2.036 \\
$\mathrm{Mg}^{2+}$ & 0.899 & $\mathrm{Cd}^{2+}$ & -1.519 \\
$\mathrm{~Pb}^{2+}$ & -0.011 & $\mathrm{Zr}^{4+}$ & -2.904 \\
$\mathrm{Fe}^{3+}$ & $7.111 \times 10^{4}$ & & \\
\hline
\end{tabular}

${ }^{a} \mathbf{L}: 2.9 \mathrm{~mL}, 1 \times 10^{-3} \mathrm{~mol} / \mathrm{L} ;{ }^{b}$ Concentration of metal ions: $0.1 \mathrm{~mL}, 1 \times 10^{-1}$ $\mathrm{mol} / \mathrm{L} ; \lambda_{\mathrm{ex}}=365 \mathrm{~nm}$.

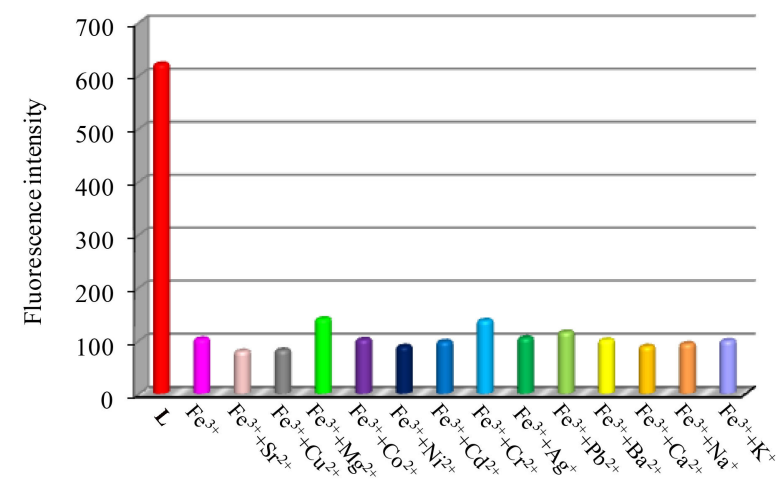

Figure 6 Effect of the disturbing metal ions on Fluorescence recognition of $\mathbf{L}$ to $\mathrm{Fe}^{3+}$

\subsection{2 $\mathrm{Zr}^{4+}$ ion detection}

Compared with $\mathrm{Fe}^{3+}$ ion, $\mathrm{Zr}^{4+}$ ion exhibits superior fluorescence enhancement effect on $\mathbf{L}$. To explore the detection effects of $\mathbf{L}$ in DMF $\left(2.9 \mathrm{~mL}, 1 \times 10^{-6} \mathrm{~mol} \cdot \mathrm{L}^{-1}\right)$ as the fluorescence probe of $\mathrm{Zr}^{4+}$, concentration-dependent experiments were further taken (Figure 7). The fluorescence intensity of $\mathbf{L}$ gradually enhanced with the increasing concentration of $\mathrm{Zr}^{4+}$ ion. The fluorescence enhancement may be attributed to the formation of $\mathrm{Zr}-\mathrm{O}$ and $\mathrm{Zr}-\mathrm{N}$ bonds in $\mathbf{L}$ and $\mathrm{Zr}^{4+}$ ions, which enhance the rigid structure of the complexes. Simultaneously, the transition from $n-\pi^{*}$ to $\pi-\pi^{*}$ in the complexes may also be the reason of fluorescence enhancement. The Job's curve was given according to the fluorescence concentration curve of $\mathbf{L}$ and $\mathrm{Zr}^{4+}$ ions (Figure $7 \mathrm{~b}$ ). The results showed that the molar fraction of $\left[\mathrm{Zr}^{4+}\right] /\left[\mathrm{L}+\mathrm{Zr}^{4+}\right]$ was 0.5 when the curve has inflection point, demonstrating $1: 1$ binding stoichiometry ration for $\mathbf{L}+\mathrm{Zr}^{4+}$. Moreover, to evaluate the detection effects of $\mathbf{L}$ to $\mathrm{Zr}^{4+}$ ion, the fluorescence spectra of $\mathbf{L}$ in DMF $\left(2.9 \mathrm{~mL}, 1 \times 10^{-5} \mathrm{~mol} \cdot \mathrm{L}^{-1}\right)$ with different concentrations of $\mathrm{Zr}^{4+}$ ion were taken (Figure 8). The experimental results show that with the addition of different concentrations $\mathrm{Zr}^{4+}$ ion, the fluorescence intensity of $\mathbf{L}$ gradually enhanced and showed a highly broad linear relationship with the concentration of $\mathrm{Zr}^{4+}$ ion from $1 \times 10^{-5}$ to $1 \times$ $10^{-4} \mathrm{~mol} \cdot \mathrm{L}^{-1}$ expressed as an equation of $y=3.592 \times$ $10^{6} x+39.24337$ and $R^{2}=0.99437$, where $y$ is fluorescence intensity of $\mathbf{L}$ with different concentration $\mathrm{Zr}^{4+}$ and $x$ is the concentration of $\mathrm{Zr}^{4+}$ ion. According to the fluorescence intensity of $\mathbf{L}$, different concentration of $\mathrm{Zr}^{4+}$ and benesi-Hildebrand equation, the detection limit of $\mathrm{Zr}^{4+}$ in $\mathbf{L}$ solution is calculated to be $3.60 \times 10^{-6} \mathrm{~mol} / \mathrm{L}$.
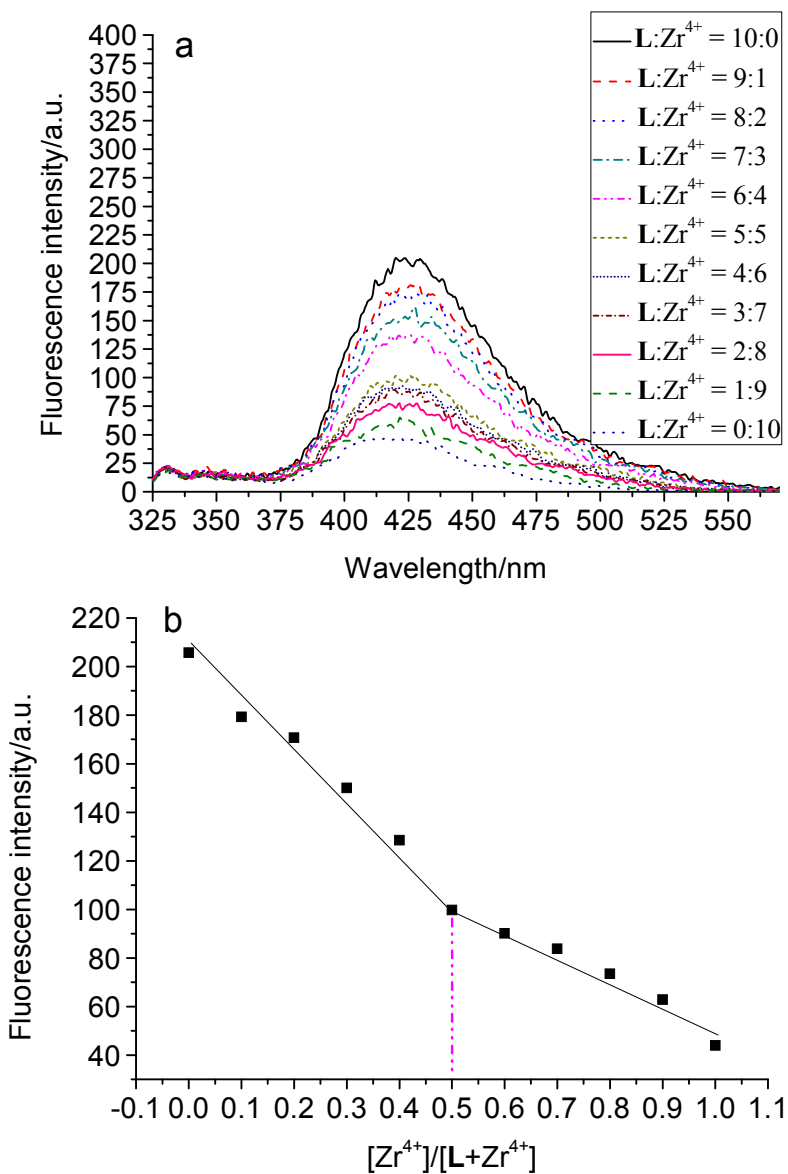

Figure 7 (a) Fluorescence spectra of $\mathbf{L}$ with different concentration $\mathrm{Zr}^{4+}$ and (b) Job's plot of $\mathbf{L}$ with $\mathrm{Zr}^{4+}\left(\lambda_{\mathrm{ex}}=300 \mathrm{~nm}\right)$ (a) $[\mathbf{L}]=2.9 \mathrm{~mL}, 1 \times 10^{-5} \mathrm{~mol} \cdot \mathrm{L}^{-1} ;\left[\mathrm{Zr}^{4+}\right]=0.1 \mathrm{~mL}, 1 \times 10^{-6} \sim 10 \times 10^{-6}$ mol $\cdot \mathrm{L}^{-1}$. (b) Complexation ratio of $\mathbf{L}$ and $\mathrm{Zr}^{4+},\left[\mathrm{Zr}^{4+}\right]=0.1 \mathrm{~mL}, 1 \times$ $10^{-6} \sim 10 \times 10^{-6} \mathrm{~mol} \cdot \mathrm{L}^{-1}$

Of course, the antiinterference ability is also very important for sensors, so a series of antijamming experiments were performed for $\mathbf{L}$ (Figure 9). Initially, the fluorescence intensity of $\mathbf{L}$ containing $\mathrm{Zr}^{4+}$ ion shows negligible change with the addition of other metal ions except $\mathrm{Cr}^{2+}$ ion. The negligible change of the fluorescence intensity indicates that $\mathbf{L}$ can detect $\mathrm{Zr}^{4+}$ ion in the presence of other metal ions $\left(\mathrm{Co}^{2+}, \mathrm{Ni}^{2+}, \mathrm{Cu}^{2+}, \mathrm{Pb}^{2+}, \mathrm{Ag}^{+}, \mathrm{Sr}^{2+}, \mathrm{Ba}^{2+}, \mathrm{Ca}^{2+}, \mathrm{Na}^{+}\right.$, $\left.\mathrm{K}^{+}, \mathrm{Cd}^{2+}, \mathrm{Mg}^{2+}\right)$.

\subsection{Acetone detection}

The solvents play an important role in the fluorescence of compound L. Different organic solvents have different effects on the fluorescence of compound $\mathbf{L}$. The fourteen different organic solvents, DMF, acetone (CP), xylene 

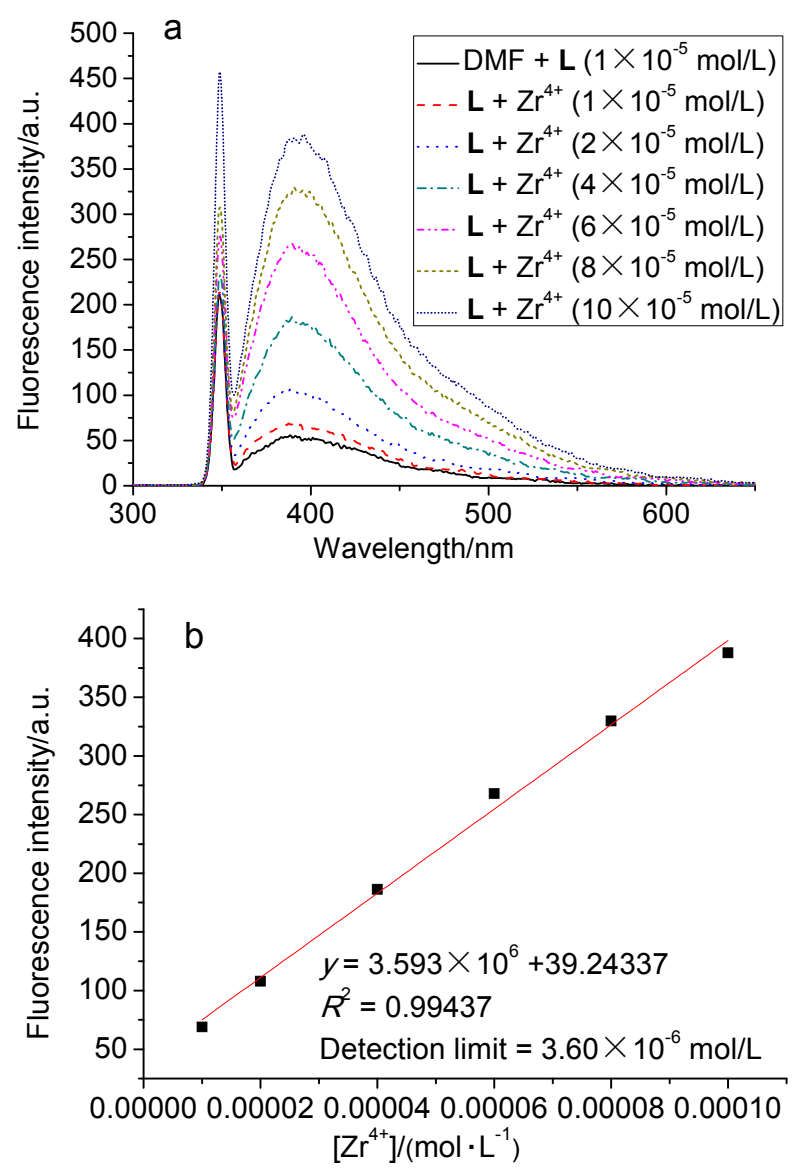

Figure 8 (a) Fluorescence spectra of $\mathbf{L}$ with different concentration $\mathrm{Zr}^{4+}$ and (b) detection limit of $\mathbf{L}$ with $\mathrm{Zr}^{4+}\left(\lambda_{\mathrm{ex}}=348 \mathrm{~nm}\right)$ (a) $[\mathbf{L}]=2.9 \mathrm{~mL}, 1 \times 10^{-5} \mathrm{~mol} \cdot \mathrm{L}^{-1} ;\left[\mathrm{Zr}^{4+}\right]=0.1 \mathrm{~mL}, 1 \times 10^{-5} \sim 10 \times 10^{-5}$ mol• $\mathrm{L}^{-1}$. (b) Detection limit of $\mathrm{Zr}^{4+} ;\left[\mathrm{Zr}^{4+}\right]=0.1 \mathrm{~mL}, 1 \times 10^{-5} \sim 10 \times$ $10^{-5} \mathrm{~mol} \cdot \mathrm{L}^{-1}$

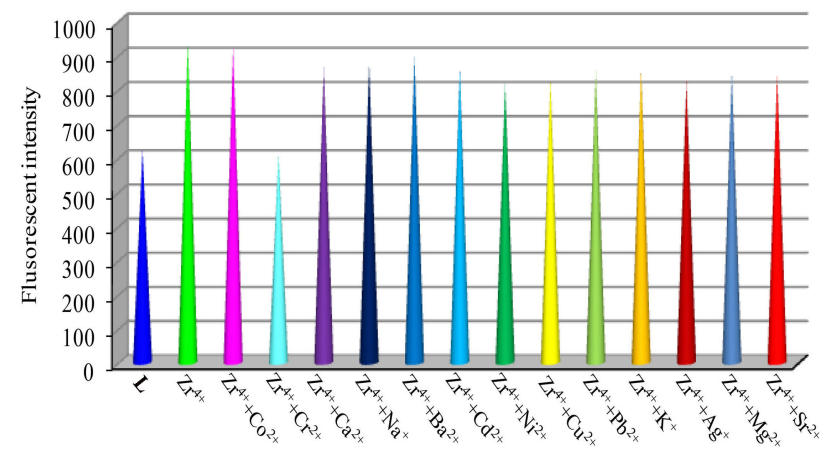

Figure 9 Effect of the disturbing metal ions on Fluorescence recognition of $\mathbf{L}$ to $\mathrm{Zr}^{4+}$

$(\mathrm{XY})$, acetonitrile $(\mathrm{ACN})$, ethyl acetate (EAC), isopropyl alcohol (IPA), dichloromethane (MC), benzene (Benzol), dimethyl sulfoxide (DMSO), tetrahydrofuran (THF), cyclohexane (CYC), 1,4-dioxane (Diox), methanol (MT) and ethanol (EA), in DMF solution were investigated and obtained experimental data finally (Figure 10). The solvents Diox, MT and EA have enhanced fluorescence effect on compound $\mathbf{L}$, and the intensity exceeds the upper limit of instrument detection. Compared with DMF, it may be due to the strong polarity and weak $p-\pi$ conjugation of $1,4-$ dioxane, which lead to the fluorescence enhancement and blue shift of $\mathbf{L}$, while the fluorescence enhancement and red shift of $\mathbf{L}$ may be due to the strong polarity of methanol and ethanol, forming hydrogen bond with $\mathbf{L}$. The results show that the initial fluorescence intensity of $\mathbf{L}(1 \times$ $10^{-5} \mathrm{~mol} \cdot \mathrm{L}^{-1}$ ) was decreased by $94.48 \%$ when only 0.1 $\mathrm{mL}$ of acetone was added. The acetone showed a strong quenching effect on fluorescence of compound $\mathbf{L}$. It may be that there is energy transfer between compound $\mathbf{L}$ and acetone, which makes the excitation of compound $\mathbf{L}$ and the absorption of acetone has some competitive effect, which leads to the rapid decrease of fluorescence intensity of $\mathbf{L}$. It was subsequently studied a possible interference of various organic solvents on selective quenching of the fluorescence of $\mathbf{L}$ caused by acetone (Figure 11). It is found that there is no significant impact of other solvent on the quenching of the fluorescence caused by the presence of acetone. Interestingly, when the $\lambda_{\mathrm{ex}}$ is larger than $300 \mathrm{~nm}$, the fluorescence quenching of compound $\mathbf{L}$ by acetone is not obvious. To some extent, the fluorescence effect of solvent on compound $\mathbf{L}$ depends on the specific $\lambda_{\text {ex }}$.

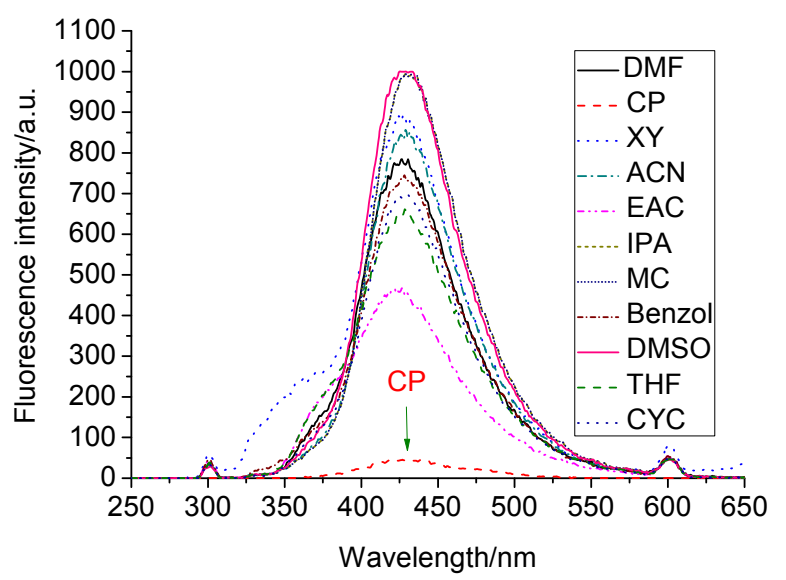

Figure 10 Fluorescence effect of organic solvent on $\mathbf{L}\left(\lambda_{\mathrm{ex}}=\right.$ $300 \mathrm{~nm}$ )

\subsection{Application to the determination of $\mathrm{Fe}^{3+}$ in urine and water samples}

The high selectivity and sensitivity make $\mathbf{L}$ promising as a fluorescent probe for detecting $\mathrm{Fe}^{3+}$ in aqueous solution. To show its potential for application in biological samples, the fluorescent $\mathbf{L}$ probe was applied to the detection of $\mathrm{Fe}^{3+}$ in human urine samples. Six human urine samples were donated by healthy volunteers. The urine samples were acidified with nitric acid and centrifuged at 5000 $\mathrm{r} / \mathrm{min}$ for $10 \mathrm{~min}$. Add $0.1 \mathrm{~mL}$ of urine directly to $\mathrm{DMF}$ solution of compound $\mathbf{L}$ without any other treatment before test analysis. The concentrations of $\mathrm{Fe}^{3+}$ ions in urine were calculated by Stern-Volmer (SV) equation and the values of $y=41790.2576 x+0.0406$ were shown in Table 2. The range of $\mathrm{Fe}^{3+}$ ions in six urine samples was about $1.68 \sim 5.78 \mu \mathrm{mol} \cdot \mathrm{L}^{-1}$ by calculation. In a sense, compound $\mathbf{L}$ can be used as a fluorescence probe to measure 
the molarity of $\mathrm{Fe}^{3+}$ ion conveniently. Of course, the flow injection ICPMS (inductively coupled plasma mass spectrometry) method can also be used to accurately analyze $\mathrm{Fe}^{3+}$ in human urine.

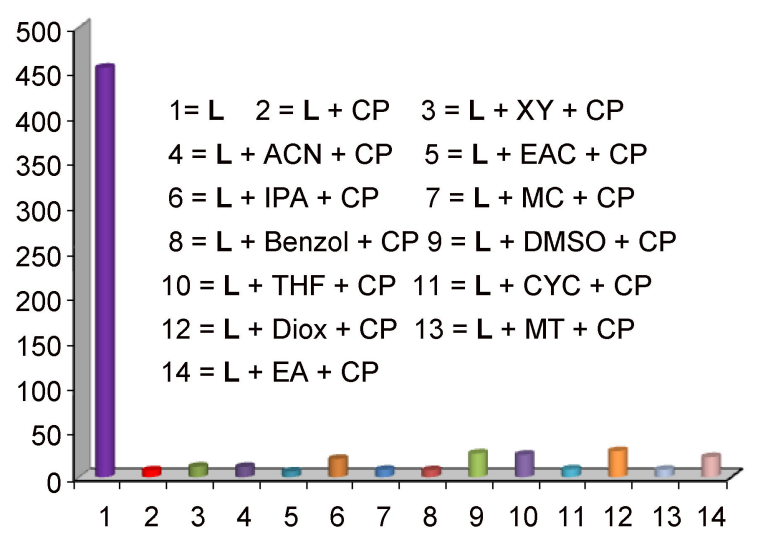

Figure 11 Interference experiment of organic solvent to $\mathbf{L}$ fluorescence $\left(\lambda_{\mathrm{ex}}=270 \mathrm{~nm}\right)$

Table 2 Detection of $\mathrm{Fe}^{3+}$ ion concentration in human urine by fluorescence of compound $\mathbf{L}^{a}$

\begin{tabular}{cccccc}
\hline \multirow{2}{*}{ Urine } & \multirow{2}{*}{$F_{0}$} & \multirow{2}{*}{$F$} & \multicolumn{2}{c}{$\left[\mathrm{Fe}^{3+}\right] /\left(\mu \mathrm{mol} \cdot \mathrm{L}^{-1}\right)$} & \multirow{2}{*}{ Error } \\
\cline { 4 - 5 } & & & $F_{0} / F^{b}$ & $Y^{c}$ & \\
\hline 1 & 573.90 & 411.89 & 5.53 & 5.78 & \pm 0.25 \\
2 & 573.90 & 449.90 & 3.86 & 4.19 & \pm 0.33 \\
3 & 573.90 & 505.17 & 1.91 & 1.89 & \pm 0.02 \\
4 & 573.90 & 510.28 & 1.75 & 1.68 & \pm 0.07 \\
5 & 573.90 & 435.67 & 4.46 & 4.79 & \pm 0.33 \\
6 & 573.90 & 475.64 & 2.91 & 3.12 & \pm 0.21 \\
\hline${ }^{a} \mathbf{L}: 2.9 \mathrm{~mL}, 1 \times 10^{-5} \mathrm{~mol} / \mathrm{L} ;$ sample: $0.1 \mathrm{~mL} ; \lambda_{\mathrm{ex}}=300 \mathrm{~nm} .{ }^{b}{ }^{b} / F=1+K_{\mathrm{SV}}$ \\
{$\left[\mathrm{Fe}^{3+}\right] ;{ }^{c} y=41790.2576 x+0.0406$.}
\end{tabular}

Besides, the tap-water and drinking-water were also tested by the above detection methods, and the concentrations of $\mathrm{Fe}^{3+}$ ions were 10.7 (9.38) and 2.28 (2.36) $\mu \mathrm{mol}$ $\mathrm{L}^{-1}$, respectively. It should be mentioned that the Environmental Protection Ministry (P. R. China) established the standard $\left(5.4 \mu \mathrm{mol} \cdot \mathrm{L}^{-1}\right)$ for the presence of $\mathrm{Fe}^{3+}$ ions in drinking $\mathrm{H}_{2} \mathrm{O}$. In this way, the tap-water cannot meet the drinking requirements, while the direct-drinking water is within the scope of national standards.

\section{Conclusions}

In summary, as a fluorescence probe, $\mathbf{L}$ shows high sensitivity and selectivity for $\mathrm{Zr}^{4+}, \mathrm{Fe}^{3+}$ ions and acetone, and the detection of $\mathrm{Fe}^{3+}$ ion can be observed by naked eye. Meanwhile, the experimental results show that the trace of $\mathrm{Fe}^{3+}$ ion could remarkably decrease the fluorescence of $\mathbf{L}$. In contrast to this, the trace of $\mathrm{Zr}^{4+}$ ion could remarkably increase the fluorescence of $\mathbf{L}$. The detection of $\mathrm{Fe}^{3+}$ ion in human urine and water was realized above two detection methods. Therefore, It is expected that the compound $\mathbf{L}$ can be used as a tunable organic fluorescence material by $\mathrm{Fe}^{3+}$ and $\mathrm{Zr}^{4+}$ ions, and also as a good probe to identify acetone in organic solvent. This study might also provide a new idea of designing fluorescent organic compound chemosensors for the sensitive and selective detection of metal ions and acetone.

\section{Experimental section}

\subsection{General methods}

All reagents were purchased commercially and used without further purification unless otherwise noted. ${ }^{1} \mathrm{H}$ NMR spectra were recorded using $500 \mathrm{MHz}$, and ${ }^{13} \mathrm{C}$ NMR spectra were recorded using $125 \mathrm{MHz}$. Elemental analyses of $\mathrm{C}, \mathrm{H}, \mathrm{N}$ in the solid samples were tested on a Vario EL analyzer (Elementar Analysensysteme $\mathrm{GmbH}$ ). FT-IR spectra were recorded in the range of $500 \sim 4000$ $\mathrm{cm}^{-1}$ on a Perkin-Elmer FTIR spectrometer using $\mathrm{KBr}$ pellets. The fluorescence spectra were acquired on an F4500 spectrometer with a $850 \mathrm{~W}$ Xenon lamp as the excitation source at room temperature.

\subsection{Synthesis of 2,2',2"-(1,3,5-triazine-2,4,6-triimi- no)tribenzoic acid (L)}

The $\mathbf{L}$ was synthesized according to the literature meth$\mathrm{od}^{[41 \sim 43]}$ with some modification (Scheme 1). Generally speaking, the reaction of cyanuric chloride is step-by-step. Low temperature is conducive to the first substitution, the second substitution at $50 \sim 60{ }^{\circ} \mathrm{C}$, and the third substitution at $110 \sim 120{ }^{\circ} \mathrm{C}$. It is verified by the following two methods. The results show that they are both suitable for the synthesis of $\mathbf{L}$ by step-by-step and one pot reaction.
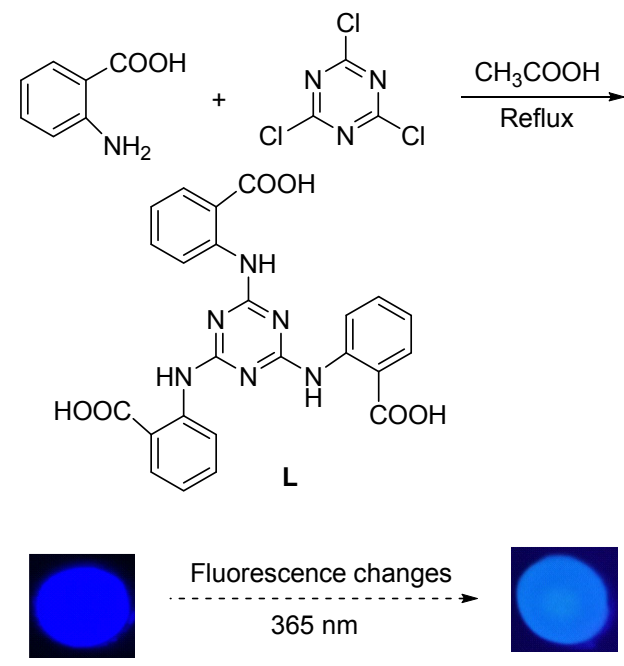

Scheme 1 Synthetic route of $\mathbf{L}$

Method 1: $2.263 \mathrm{~g}$ (16.5 mmol) of 2-aminobenzoic acid and $25 \mathrm{~mL}$ of $\mathrm{AcOH}$ were added to a $100 \mathrm{~mL}$ round bottom flask. $0.922 \mathrm{~g}(5.0 \mathrm{mmol})$ of cyanuric chloride was dissolved in $20 \mathrm{~mL}$ of $\mathrm{AcOH}$ and slowly dripped into the round bottom flask under the ice bath. The mixture reacts at $0{ }^{\circ} \mathrm{C}$ for $5 \mathrm{~h}$. Then, the reaction continued for $5 \mathrm{~h}$ at $50{ }^{\circ} \mathrm{C}$. Finally, the reaction refluxed at $120{ }^{\circ} \mathrm{C}$ for $20 \mathrm{~min}$. The suspension was filtered and the product was washed several times with boiling water and ethanol, and then the product was dried in vacuum dryer at $80{ }^{\circ} \mathrm{C}$ for one day. $2.345 \mathrm{~g}$ of white powder was collected in $96.4 \%$ yield. 
Method 2: $0.922 \mathrm{~g}(5.0 \mathrm{mmol})$ of cyanuric chloride and $2.263 \mathrm{~g}(16.5 \mathrm{mmol})$ of 2-aminobenzoic acid were dissolved in $50 \mathrm{~mL}$ of $\mathrm{AcOH}$ in a $100 \mathrm{~mL}$ round-bottom flask. The mixture was stirred and refluxed immediately at $120{ }^{\circ} \mathrm{C}$ for $15 \mathrm{~min}$, generating a pink aqueous suspension. Then, the suspension was filtered and the product was washed several times with boiling water and ethanol, and then the mixture was dried in vacuum dryer at $80{ }^{\circ} \mathrm{C}$ for one day. $2.352 \mathrm{~g}$ of white powder was collected in $96.7 \%$ yield.

2,2',2"-(1,3,5-Triazine-2,4,6-triimino)tribenzoic acid (L): m.p. $\geqslant 330{ }^{\circ} \mathrm{C}$ (dec.); ${ }^{1} \mathrm{H}$ NMR (DMF- $\left.d_{7}, 500 \mathrm{MHz}\right) \delta$ : 11.19 (s, 3H, COOH), $8.86(\mathrm{~d}, J=10.0 \mathrm{~Hz}, 3 \mathrm{H}, \mathrm{ArH})$, $8.13 \sim 8.15(\mathrm{~m}, 3 \mathrm{H}, \mathrm{ArH}), 7.68 \sim 7.72(\mathrm{~m}, 3 \mathrm{H}, \mathrm{ArH})$, $7.16 \sim 7.20(\mathrm{~m}, 3 \mathrm{H}, \mathrm{ArH})$; IR (KBr) v: 3440, 3312, 1685, $1610,1567,1523,1413,1161 ;{ }^{13} \mathrm{C}$ NMR (DMF- $d_{7}, 125$ $\mathrm{MHz}) \delta: 170.1,164.5,142.2,133.8,131.5,121.6,120.9$, 123.3, $116.3 \mathrm{~cm}^{-1}$. Anal. calcd for $\mathrm{C}_{24} \mathrm{H}_{18} \mathrm{~N}_{6} \mathrm{O}_{6}$ : C 59.26, $\mathrm{H}$ 3.73, N 17.28; found C 58.31, H 3.58, N 16.57.

\section{References}

[1] Wang, P.; Okamura, T.; Zhou, H. P.; Sun, W. Y.; Tian, Y. P. Chin. Chem. Lett. 2013, 24(1), 20.

[2] Xu, H.; Hu, H. C.; Cao, C. S.; Zhao, B. Inorg. Chem. 2015, 54(10), 4585.

[3] Wang, J.; Jiang, M.; Yan, L.; Peng, R.; Huangfu, M. J.; Guo, X. X.; Li, Y.; Wu, P. Y. Inorg. Chem. 2016, 55(24), 12660.

[4] Yan, W.; Zhang, C.; Chen, S. G.; Han, L. J.; Zheng, H. G. ACS Appl. Mater. Interfaces 2017, 9(19), 1629.

[5] Arici, M. Cryst. Growth Des. 2017, 17(10), 5499.

[6] Li, P.; Zhou, L. J.; Yang, N. N.; Sui, Q.; Gong, T.; Gao, E. Q. Cryst. Growth Des. 2018, 18(11), 7191.

[7] Tang, S. F.; Hou, X. M. Cryst. Growth Des. 2019, 19(1), 45.

[8] Zheng, M.; Tan, H. Q.; Xie, Z. G.; Zhang, L. G.; Jing, X. B.; Sun, Z. C. ACS Appl. Mater. Interfaces 2013, 5(3), 1078.

[9] Xu, X. Y.; Yan, B. ACS Appl. Mater. Interfaces 2015, 7(1), 721.

[10] Wen, G. X.; Wu, Y. P.; Dong, W. W.; Zhao, J.; Li, D. S.; Zhang, J. Inorg. Chem. 2016, 55(20), 10114.

[11] Rao, P. C.; Mandal, S. Inorg. Chem. 2018, 57(19), 11855

[12] Gogoi, C.; Biswas, S. Dalton Trans. 2018, 47(41), 14696

[13] Yu, C. Y.; Sun, X. D.; Zou, L. F.; Li, G. H.; Zhang, L. R.; Liu, Y. L. Inorg. Chem. 2019, 58(6), 4026.

[14] He, H. M.; Zhu, Q. Q.; Li, C. P.; Du, M. Cryst. Growth Des. 2019 , $19(2), 694$.

[15] Jia, H. J.; Han, L. M.; Zhu, N.; Gao, Y. Y.; Wang, Y. Q.; Suo, Q. L. Chin. J. Org. Chem. 2019, 39(6), 1753 (in Chinese). (贾慧劼, 韩利民, 竺宁, 高媛媛, 王亚琦, 索全伶, 有机化学, 2019, 39(6), 1753.)

[16] Liu, M. L.; Chen, B. B.; Li, C. M.; Huang, C. Z. Sci. China: Chem. 2019, 62(8), 968.

[17] Yu, L.; Qiao, Y. M.; Miao, L. X.; He, Y. Q.; Zhou, Y. Chin. Chem. Lett. 2018, 29(11), 1545.

[18] Pang, C. M.; Luo, S. H.; Hao, Z. F.; Gao, J.; Huang, Z. H.; Yu, J. H.; Yu, S. M.; Wang, Z. Y. Chin. J. Org. Chem. 2018, 38(10), 2606 (in Chinese).
(庞楚明, 罗时荷, 郝志峰，高健，黄召昊，余家海，余思敏，汪 朝阳, 有机化学, 2018, 38(10), 2606.)

[19] Sheng, K.; Lu, H. F.; Sun, A. B.; Wan, Y. M.; Liu, Y. T.; Chen, F.; Bian, W. C.; Li, Y.; Kuang, R.; Sun, D. Chin. Chem. Lett. 2019, 30(4), 895

[20] Wang, J. H.; Fan, Y. d.; Lee, H. W.; Yi, C. Q.; Cheng, C. M.; Zhao, X.; Yang, M. ACS Appl. Nano Mater. 2018, 1(7), 3747.

[21] Huang, J. J.; Yu, J. H.; Bai, F. Q.; Xu, J. Q. Cryst. Growth Des. 2018, 18(9), 5353.

[22] Lu, S. Q.; Liu, Y. Y.; Duan, Z. M.; Wang, Z. X.; Li, M. X.; He, X. Cryst. Growth Des. 2018, 18(8), 4602.

[23] Smith, J. A.; Singh-Wilmot, M. A.; Carter, K. P.; Cahill, C. L.; August Ridenour, J. Cryst. Growth Des. 2019, 19(1), 305.

[24] Fan, K.; Bao, S. S.; Nie, W. X.; Liao, C. H.; Zheng, L. M. Inorg. Chem. 2018, 57(3), 1079.

[25] Zhang, H. J.; Fan, R. Q.; Chen, W.; Fan, J. Z.; Dong, Y. W.; Song, Y., Du, X.; Wang, P.; Yang, Y. L. Cryst. Growth Des. 2016, 16(9), 5429.

[26] Zhang, C. H.; Shi, H. Z.; Sun, L. B.; Yan, Y.; Wang, B. L.; Liang, Z. Q.; Wang, L.; Li, J. Y. Cryst. Growth Des. 2018, 18(12), 7683.

[27] Yoon, C. S.; Choi, M. J.; Jun, D. W.; Zhang, Q.; Kaghazchi, P.; Kim, K. H.; Sun, Y. K. Chem. Mater. 2018, 30(5), 1808 .

[28] Yoon, C. S.; Kim, U. H.; Park, G. T.; Kim, S. J.; Kim, K. H.; Kim, J.; Sun, Y. K. Energy Lett. 2018, 3(7), 1634.

[29] Meng, H. M.; Fu, T.; Zhang, X. B.; Wang, N. N.; Tan, W. H.; Shen, G. L.; Yu, R. Q. Anal. Chem. 2012, 84(5), 2124.

[30] Wang, B; Yang, Q.; Guo, C.; Sun, Y. X.; Xie, L. H.; Li, J. R. ACS Appl. Mater. Interfaces 2017, 9(11), 10286.

[31] Xu, M. M.; Kong, X. J.; He, T.; Wu, X. Q.; Xie, L. H.; Li, J. R. Inorg. Chem. 2018, 57(22), 14260.

[32] He, P.; Tang, L. J.; Zhong, K. L.; Hou, S. H.; Yan, X. M. Chin. J. Org. Chem., 2017, 37(2), 423 (in Chinese). (何平，汤立军，钟克利，侯淑华，燕小梅，有机化学，2017, $37(2), 423$.)

[33] Yu, L.; Qiao, Y. M.; Miao, L. X.; He, Y. Q.; Zhou, Y. Chin. Chem. Lett. 2018, 29(11), 1545 .

[34] Wang, T.; Liu, Q. H.; Gao, Y,; Yang, X. Y.; Yang, W. T.; Dang, S. Chin. Chem. Lett. 2016, 27(4), 497.

[35] Zhang, Q. S.; Wang, J.; Kirillov, A. M.; Dou, W.; Xu, C.; Xu, C. L.; Yang, L. Z.; Fang, R.; Liu, W. S. ACS Appl. Mater. Interfaces 2018, 10(28), 23976.

[36] Zhao, X. X.; Wang, S. L.; Zhang, L. Y.; Liu, S. Y.; Yuan, G. Z. Inorg. Chem. 2019, 58(4), 2444.

[37] Wang, X.; Fan, W. D.; Zhang, M.; Shang, Y. Z.; Wang, Y. T.; Liu, D.; Guo, H. L.; Dai, F. N.; Sun, D. F. Chin. Chem. Lett. 2019, 30(3), 801.

[38] Huang, W. H.; Ren, J.; Yang, Y. H.; Li, X. M.; Wang, Q.; Jiang, N.; Yu, J. Q.; Wang, F.; Zhang, J.. Inorg. Chem. 2019, 58(2), 1481.

[39] Chen, Z.; Sun, Y. W.; Zhang, L. L.; Sun, D.; Liu, F. L.; Meng, Q. G.; Wang, R. M.; Sun, D. F. Chem. Commun. 2013, 49(98), 11557.

[40] Wang, R.; Dong, X. Y.; Xu, H.; Pei, R. B.; Ma, M. L.; Zang, S. Q.; Hou, H. W.; Mak, T. C. W. Chem. Commun. 2014, 50(65), 9153.

[41] Karuehanon, W.; Fanfuenha, W.; Rujiwatra, A.; Pattarawarapan, M. Tetrahedron Lett. 2012, 53(27), 3486.

[42] Wang, X. S.; Liang, J; Li, L.; Lin, Z. J.; Bag, P. P.; Gao, S. Y.; Huang, Y. B.; Cao, R. Inorg. Chem. 2016, 55(5), 2641.

[43] Kolmakov, K. A. J. Heterocycl. Chem. 2008, 45(2), 533. 